\title{
Changes in Cell Ultrastructure and Zeatin Riboside Concentrations in Hedera helix, Pelargonium zonale, Prunus avium, and Rubus ulmifolius Leaves Infected by Fungi
}

\author{
M. López-Carbonell, Assistant Professor, A. Moret and M. Nadal, Associate Professors, Unit of Plant Physiology, \\ Faculty of Biology, University of Barcelona, Avda. Diagonal 645, E-08028 Barcelona, Spain
}

\begin{abstract}
López-Carbonell, M., Moret, A., and Nadal, M. 1998. Changes in cell ultrastructure and zeatin riboside concentrations in Hedera helix, Pelargonium zonale, Prunus avium, and Rubus ulmifolius leaves infected by fungi. Plant Dis. 82:914-918.

Ultrastructural alterations in epidermal and mesophyll cells and variations in endogenous zeatin riboside (ZR) concentrations were studied in leaves of Hedera helix, Pelargonium zonale, Prunus avium, and Rubus ulmifolius infected by Colletotrichum trichellum, Puccinia pelargoniizonalis, Cercospora circumscissa, and Phragmidium violaceum, respectively. Infected tissues showed a marked increase in vesicles, myelin-like structures, and electron-dense bodies associated with plasma membranes. The main changes to the chloroplast included thylakoid swelling and disruption of the chloroplast envelope. The ZR content of the green islands was always higher than that of the yellow, senescent parts of the same leaves; the highest levels of ZR were observed in the green areas of infected Prunus avium (462.2 $\mathrm{pmol} \mathrm{g}^{-1}$ fresh weight $[\mathrm{FW}]$ ) and Rubus ulmifolius (441.6 pmol g-1 FW), followed by Pelargonium zonale ( $263.8 \mathrm{pmol} \mathrm{g}^{-1} \mathrm{FW}$ ) and Hedera helix (219.8 $\left.\mathrm{pmol} \mathrm{g}^{-1} \mathrm{FW}\right)$; the yellow zones of the same leaves had lower ZR contents (78.3, 73.9, 73.6, and $18.1 \mathrm{pmol} \mathrm{g}^{-1} \mathrm{FW}$, respectively). The green islands had almost the same ZR content as the controls (green healthy leaves). These results suggest a relationship between ultrastructural alterations and ZR content of these plant species (blackberry, cherry, English ivy, geranium) in reacting to this type of biotic stress and could confirm the role of cytokinins as senescence-delaying hormones.
\end{abstract}

Additional keywords: blackberry, cherry, enzyme-linked immunosorbent assay, English ivy, geranium

Plant defenses against a variety of biotic and abiotic stress agents are controlled by phytohormones (29). Cytokinins generally are considered adenine-derived plant growth regulators with several important biological properties. Cytokinins are predominantly root-borne phytohormones (9) distributed in the shoot via the xylem stream (11). In the hormone message theory, they are considered root signals that mediate the transport of the photosynthates to various parts of the plant $(5,12)$.

There is increasing evidence that cytokinins are the major endogenous regulators of plant development and may be involved in the formation of visible disease symptoms (4). According to Mothes' theory (19), cytokinins may play an important role in plant disease resistance. It has been shown experimentally that in plant infections caused by powdery mildews, rusts, and other pathogenic fungi the level of cytokinins regulates disease development in its early stages (29). It generally is accepted that root-

Corresponding author: M. López-Carbonell E-mail: martal@porthos.bio.ub.es

Accepted for publication 4 May 1998.

Publication no. D-1998-0618-01R

(C) 1998 The American Phytopathological Society produced cytokinins play a role in both the synthesis and maintenance of chlorophyll and affect both chloroplast development and metabolism $(1,13)$. It also is widely accepted that one function attributable to cytokinins is the inhibition of plant senescence (14).

When certain fungi that cause rust and mildew diseases infect leaves, areas of dead and dying cells are produced. As leaves senesce, these necrotic areas are often surrounded by several green and starch-rich cells, even when the rest of the leaf has become yellow and senescent. These green "islands" are rich in cytokinins, which are probably synthesized by the fungus (7).

The aim of this study was to determine both the ultrastructural changes and the endogenous cytokinin (zeatin riboside [ZR]) concentrations in the green and yellow tissues of infected leaves of Hedera helix L., Pelargonium zonale Willd., Prunus avium L., and Rubus ulmifolius Schott to contribute to our knowledge of this physiological host-pathogen relationship.

\section{MATERIALS AND METHODS}

Plants of Hedera helix (English ivy), Pelargonium zonale (geranium), Prunus avium (cherry), and Rubus ulmifolius (blackberry) growing in Collserola Park, Barcelona, Spain, were chosen for this study. These species were infected by Colletotrichum trichellum (Fr.:Fr.) M.M. Duke, Puccinia pelargoniizonalis Doidge, Cercospora circumscissa Sacc., and Phragmidium violaceum (C.F. Schultz) Wint., respectively. Leaves with green spots were collected during early autumn and examined under a dissecting microscope (Meiji, Tokyo). Green spots were excised from the yellow tissues of the same leaves. Samples of both types of tissue were treated with a lactophenol solution and stained with cotton blue to determine whether fungal mycelium was present. Green healthy leaves from each of the four plant species were taken as controls.

Samples for transmission electron microscopy $\left(\approx 1 \mathrm{~mm}^{2}\right)$ were fixed in $2 \%$ glutaraldehyde in $0.1 \mathrm{M}$ phosphate buffer $(\mathrm{pH}$ 7.2) for $4 \mathrm{~h}$ at $23^{\circ} \mathrm{C}$. Postfixation with $1 \%$ osmium tetroxide in $0.18 \mathrm{M}$ phosphate buffer $(\mathrm{pH} 7.2)$ was done for $1 \mathrm{~h}$ at $23^{\circ} \mathrm{C}$. Specimens were dehydrated in a graded series of ethanol and embedded in Spurr's low-viscosity epoxy resin (26). Ultrathin sections $(50$ to $60 \mathrm{~nm}$ ) were cut with a diamond knife. Sections were stained with $2 \%$ uranyl acetate and 2\% lead citrate. Photomicrographs were obtained with a Phillips 301 transmission electron microscope (Phillips Analytical, Eindhoven, Netherlands) at an accelerating voltage of $80 \mathrm{kV}$. For each plant, an average of 80 to 90 randomly chosen mesophyll cells were examined.

After determining fresh mass, samples were frozen in liquid nitrogen and stored at $-20^{\circ} \mathrm{C}$ for hormone analysis. The $\mathrm{ZR}$ equivalents content was determined by adapting a method described by Prinsen et al. (21), essentially according to the method of Thomas et al. (27). After grinding with a mortar and pestle, samples were extracted overnight at $-20^{\circ} \mathrm{C}$ in $80 \%$ methanol ( $9 \mathrm{ml} \mathrm{g}^{-1}$ fresh weight). After centrifugation $\left(24,000 \times g\right.$ for $15 \mathrm{~min}$ at $\left.4^{\circ} \mathrm{C}\right)$, the extracts were purified on two reversedphase- $\mathrm{C}_{18}$ cartridges (500 mg, Waters Corporation, Milford, MA) and eluted with $80 \%$ methanol. The eluates were dried under vacuum at $35^{\circ} \mathrm{C}$ with a rotary evaporator, and concentrates were rehydrated in deionized water and analyzed by enzyme-linked immunosorbent assay with ZR-specific monoclonal antibodies (Phytosciences, Chatou Cedex, France). The cross-reactivity of the antibodies used was as follows: ZR at $100 \%$, zeatin at $88 \%$, and zeatin monophosphate at $84 \%$. These antibodies recognize only Ztype cytokinins, not dihydrozeatin, isopen- 

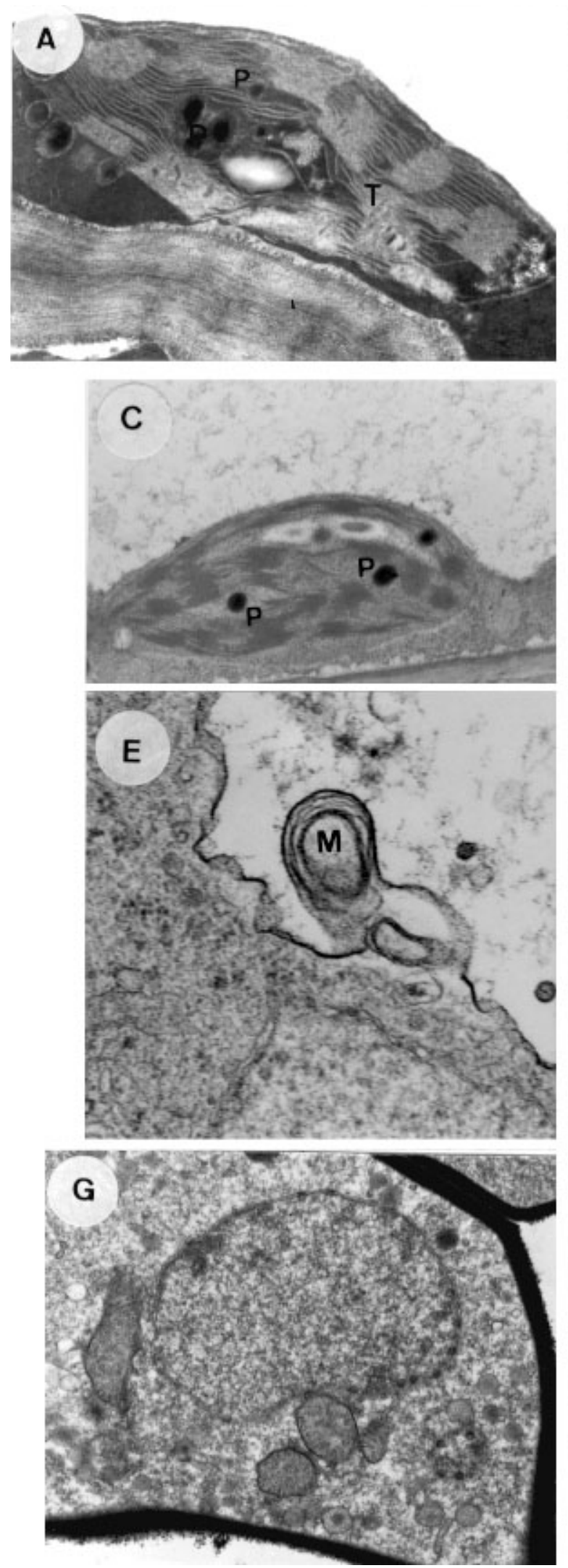
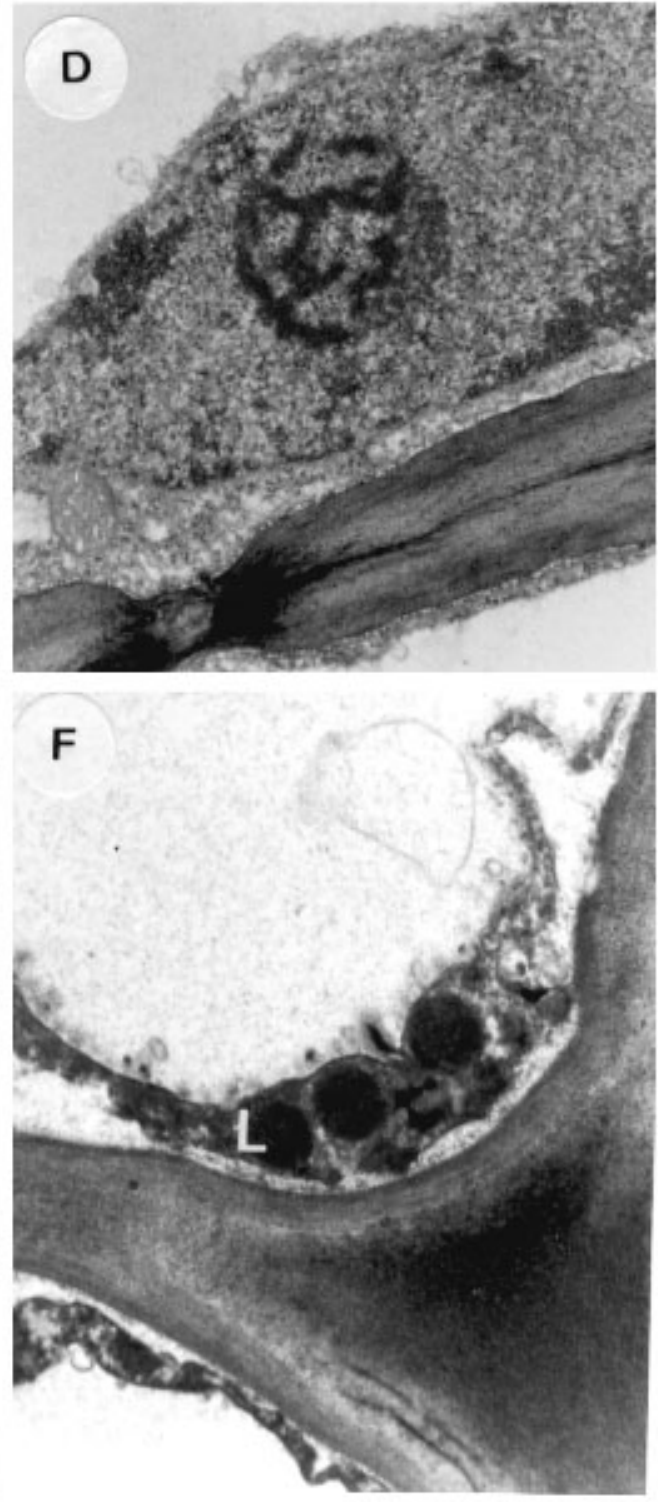

Fig. 1. (A) Mesophyll cell chloroplast of an infected English ivy leaf containing bent thylakoids (T) and plastoglobuli (P), as well as clear regions in the stroma; $\times 19,250$. (B) Swollen chloroplast of a mesophyll cell of an infected geranium leaf with the external envelope broken at different points (arrows) and plastoglobuli of different sizes inside; $\times 25,200$. (C) Mesophyll chloroplast of a noninfected geranium leaf; $\times 23,100$. (D) Nucleus and nucleoli of a noninfected vascular system cell of English ivy leaf showing partial aggregation of the chromatin; $\times 15,400$. (E) A myelin-like (M) structure formed from the tonoplast of a mesophyll cell of English ivy; $\times 47,700$. (F) Lipid (L) accumulation between the plasma membrane and the tonoplast of a plasmolyzed mesophyll cell of geranium; $\times 15,400$. (G) Nucleus of a vascular system cell from a noninfected leaf of English ivy with only a slightly aggregated chromatin and well-preserved membranes; $\times 14,700$. 

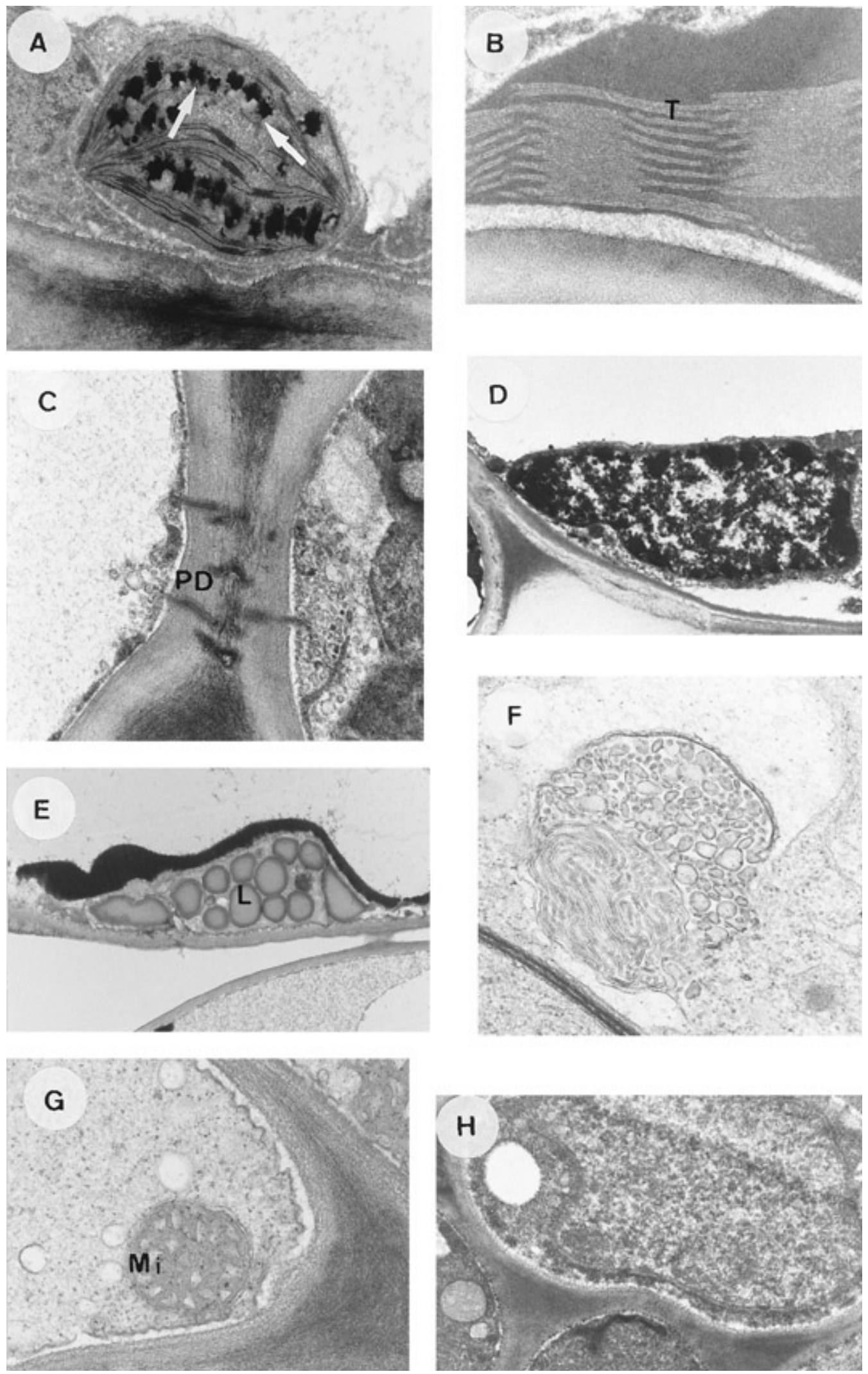

Fig. 2. (A) Infected mesophyll chloroplast of a cherry leaf with a swollen aspect and several electron-dense structures inside (arrows); $\times 14,700$. (B) Detail of a chloroplast of a noninfected cherry leaf with well-orientated thylakoids (T); $\times 29,900$. (C) Plasmodesmata (PD) between two vascular systems of infected cherry cells in contact with small vesicles in the cytoplasm of both cells; $\times 25,200$. (D) Nucleus of a noninfected vascular system cherry cell, where no clear condensation of the chromatin is seen; $\times 19,250$. (E) Lipid (L) accumulation is frequently seen in infected blackberry cells; $\times 9,100$. (F) Many small vesicles are contained in the dense cytoplasm of the vascular system cells of blackberry; $\times 35,000$. (G) Cell membranes are well preserved in control noninfected blackberry leaves; $\times 10,000$; $\mathrm{Mi}=$ mitochondria. $(\mathbf{H})$ Nucleus of a control mesophyll cell of blackberry with condensed chromatin distributed homogeneously; $\times 4,550$. 
tenyladenine, or isopentenyladenosine types (iP-type cytokinins). ZR standard solutions (from 0.03 to $30 \mathrm{pmol} / 0.1 \mathrm{ml}$ of sample [volume per well]) were used for calibration. Standards and samples were tested in triplicate and analyzed by a paired $t$ test. Data are expressed as picomoles of ZR equivalents per gram fresh weight.

\section{RESULTS}

The observations we made under light microscopy showed that mycelium was present in infected tissues but not in green healthy controls.

Leaf ultrastructure. Mesophyll cells of English ivy (Hedera helix) infected by Colletotrichum trichellum contained swollen chloroplasts with electron-dense inclusions in the stroma (plastoglobuli). The granal and stromatic thylakoids appeared bent (Fig. 1A). On the other hand, vascular system cells were still well preserved, and the plastids contained numerous plastoglobuli. Infected cells of English ivy plants showed partial aggregation of the nuclear chromatin and nucleoli (Fig. 1D) compared to green control leaves (Fig. 1G). These infections also caused marked alterations to epidermal and mesophyll cells of English ivy plants. There were frequent undulations and invaginations of the plasma membrane that led to the formation of small vesicles enclosed by larger ones and some myelin-like structures (Fig. 1E).

The chloroplasts of geranium (Pelagonium zonale) leaves infected by Puccinia pelargonii-zonalis were swollen and compact and contained several plastoglobuli. Most of the stroma was occupied by the thylakoids, which were in an inclined orientation, and the chloroplast envelope was broken at different points (Fig. 1B); control leaves had well-preserved membranes (Fig. 1C). Mesophyll cells of geranium showed numerous invaginations of the plasma membrane and tonoplast, which led to the formation of vesicles of different sizes. Plasmolysis and lipid accumulation also were evident in the vascular system cells of infected geranium leaves (Fig. 1F). Only a slightly condensed chromatin in the infected tissues of geranium were detected.

Cherry (Prunus avium) leaves showed marked alterations in cell ultrastructure (Fig. 2). The chloroplasts of infected leaves also were swollen, with many irregularly shaped electron-dense structures and thylakoids that had an undulate orientation (Fig. 2A), which were not observed in controls (Fig. 2B). Numerous small vesicles were formed from the plasma membrane and the tonoplast, both in mesophyll and vascular system cells (Fig. 2C). The nucleus of these cells had an electron-dense aspect, with chromatin distributed homogeneously (Fig. 2D), which was not observed in the noninfected tissues of these plants. Effects similar to those observed in infected tissues of cherry were observed in blackberry leaves (Rubus ulmifolius) infected by Phragidium violac- eum. The chloroplasts of the epidermal and mesophyll cells were swollen and contained numerous plastoglobuli. A large accumulation of lipid bodies in the cytoplasm of mesophyll cells was observed (Fig. 2E). Invaginations of the plasma membrane in epidermal and mesophyll blackberry cells also were abundant (Fig. 2F). The membranes of noninfected control blackberry cells were well preserved (Fig. 2G). Aggregated chromatin was observed in the infected tissues of these plants but not in the controls (Fig. 2H).

Endogenous ZR content. The results of the endogenous content of ZR are shown in Table 1. The green "islands" of infected English ivy leaves had 12-fold more ZR equivalents than the yellow infected tissues of the same leaves. In some cases, such as geranium, the ZR equivalents content of the green islands was threefold higher than that observed in the yellow tissues of the same leaves. The concentrations of ZR equivalents obtained in the green islands of cherry tree leaves were fivefold higher than that in the yellow tissues. Finally, the ZR equivalents content of the green tissues of blackberry was sixfold higher than those in the yellow tissues. The four plant species studied had a green island ZR equivalents content higher than that of the senescent tissues from the same leaves but slightly lower than that of green healthy leaves taken as controls (Table 1).

\section{DISCUSSION}

In the species studied (Hedera helix, Pelargonium zonale, Prunus avium, and $\mathrm{Ru}$ bus ulmifolius), some major alterations appeared in epidermal and mesophyll cells after infection by these biotrophic fungi (Colletotrichum trichellum, Puccinia pelargonii-zonalis, Cercospora circumscissa, and Phragmidium violaceum, respectively). These results are comparable to those reported by other authors on plant responses to biotic and abiotic stress conditions (3, $6,10,16-18,22,23)$; the effects of fungal infection we observed on chloroplasts were similar among the four plant species studied and did not appear to be a unique response to fungal infection. Other researchers $(3,6,10,16-18,22,23)$ have reported swollen chloroplasts and irregularly shaped thylakoids. Moreover, displacement of lipids from various cell membranes, increasing vesiculation within cells, and formation of myelin-like membrane structures also were observed. Changes in the number of cristae in the mitochondria and modifications of Golgi apparatus have been described previously $(3,17)$ in cells exposed to abiotic stress.

The changes we observed in infected tissues mainly were related to cell membrane damage, lipid accumulation, and chloroplast disorganization. It is well known that changes in membrane permeability are often the first effects of pathogenic invasion (10). Because membranes are responsible for ion transport, alterations in ion fluxes may result in marked biochemical changes within cells and may play an important role in recognition of invasion and intercellular signaling for defense response activation (10).

Transport of materials in infected cells of cherry leaves possibly could be done on both sides of the plasmodesmata. The partial aggregation of nuclear chromatin observed in infected English ivy leaves, which could indicate a decrease in DNA replication and transcription, also is consistent with previous reports (2); a more condensed nuclear chromatin and compact structure of the nucleoli have been observed in plant tissues under stress (3). These ultrastructural alterations of nuclei, plastids, and cell membranes were observed in green island tissues but not in healthy green noninfected leaves. Nevertheless, the results on responses of cell organelles to biotic stresses (such as fungal pathogens) need to be studied further.

Zeatin and ZR are the most abundant cytokinins in many plants $(8,24)$, and zeatinlike compounds are the major endogenous cytokinins in leaves (28). Yellow leaves contain fewer endogenous cytokinins than green leaves, and some studies have demonstrated that the cytokinins transported to yellow tissues are metabolized much faster (28); this fact could explain, in part, the low levels of cytokinins detected. Several studies have reported an increase in cytokinins in response to invasion by pathogens $(7,15,29)$. A close correlation between zeatin content and the degree of resistance to stem rust and powdery mildew has been established (30).

There is a clear increase in the total amount of cytokinin metabolites in virusinfected plants compared to healthy plants, due especially to the marked increase of ZR and iP-9-G concentrations (4). Our results are consistent with these findings. In this study, the endogenous ZR levels of the infected leaves were always higher in green tissues than in yellow tissues (yellow-sen-

Table 1. Variations in zeatin riboside (ZR) equivalents content in infected green and yellow tissues and green healthy controls of Hedera helix, Pelargonium zonale, Prunus avium, and Rubus ulmifolius ( $n=3 \pm$ standard error)

\begin{tabular}{llcc}
\hline & \multicolumn{2}{c}{ ZR equivalents (pmol g-1 fresh weight) } \\
\cline { 2 - 4 } Source & Green tissue & Yellow tissue & Control \\
\hline Hedera helix & $219.8 \pm 69$ & $18.1 \pm 2$ & $297.2 \pm 68$ \\
Pelargonium zonale & $263.8 \pm 108$ & $73.6 \pm 23$ & $282.4 \pm 102$ \\
Prunus avium & $462.2 \pm 162$ & $78.3 \pm 19$ & $488.7 \pm 158$ \\
Rubus ulmifolius & $441.6 \pm 140$ & $73.9 \pm 26$ & $480.2 \pm 145$ \\
\hline
\end{tabular}


escent parts of the same leaves). We suggest that the high levels of cytokinins detected in infected leaves tissues could be synthesized in the green islands of the leaf. Researchers have shown that the larger amount of cytokinins (especially in conjugated zeatins) transported from the roots to the shoots cause the slow senescence of some rice cultivars (25).

Because cytokinins act in sink-source relations $(5,11)$, presumably they also may contribute to the maintenance of food reserves for the fungus and influence the subsequent course of the disease (24). It has been demonstrated that cytokinin production by Pyrenopeziza brassicae in plants may benefit its interaction with the host, so the presence of cytokinins in a leaf causes nutrient translocation toward the source that maintains the host tissue in a healthy condition (providing organic and inorganic nutrients) that contributes to the ability of the fungus to live biotrophically during the early phase of infection (20).

It is of interest for disease management to determine whether the increase in $\mathrm{ZR}$ equivalents content is related to the capacity of plants to resist such pathogens. If this is the case, it would be of interest to improve some plant cultivars to stimulate their capacity to synthesize endogenous cytokinins. More studies are needed to further evaluate this relationship.

\section{ACKNOWLEDGMENTS}

We thank E. Prinsen (Department of Plant Biology, University of Antwerpen, Belgium) for critical reading of the manuscript and $\mathrm{N}$. Cortadellas and A. Ribera (Serveis Científico-Tècnics, Universitat de Barcelona, Spain) for their valuable technical assistance. We also thank R. Rycroft for the correction of the English text.

\section{LITERATURE CITED}

1. Alberte, R. S., and Naylor, W. A. 1975. The role of cytokinins in chloroplast lamellar development. Plant Physiol. 55:1079-1081.

2. Ciamporová, M., and Mistrík, I. 1991. The Plant Cell Under Unfavourable Conditions. Veda, Bratislava, Slovakia.

3. Ciamporová, M., and Mistrík, I. 1993. The ultrastructural response of root cells to stressful conditions. Environ. Exp. Bot. 33:11-26.

4. Dermastia, M., and Ravnikar, M. 1996. Al- tered cytokinin pattern and enhanced tolerance to potato virus $\mathrm{Y}^{\mathrm{NTN}}$ in the susceptible potato cultivar (Solanum tuberosum cv. Igor) grown in vitro. Physiol. Mol. Plant Pathol. 48:65-71.

5. Fetene, M., and Beck, E. 1993. Reversal of sink-source relations of Urtica dioica L. plants by increasing cytokinin import into the shoot. Bot. Acta 106:235-240

6. Giles, K. L., and Beardsell, M. F. 1974. Cellular and ultrastructural changes in mesophyll and bundle sheath cells of maize in response to water stress. Plant Physiol. 54:208-212.

7. Greene, E. M. 1980. Cytokinin production by microorganisms. Bot. Rev. 46:25-74.

8. Hopkins, W. G. 1995. Cytokinins. Pages 301304 in: Introduction to Plant Physiology. John Wiley \& Sons, New York.

9. Horgan, R. 1992. Present and future prospects of cytokinins research. Pages 3-13 in: Physiology and Biochemistry of Cytokinins in Plants. M. Kaminek, D. W. S. Mok, and E. Zazimalová, eds. Society for Plant Biology Academic Publishers, Netherlands.

10. Isaac, S. 1991. Physiological changes in host plant tissues. Pages 243-248 in: Fungal-Plant Interactions. Chapman-Hall, London.

11. Jackson, M. B. 1993. Are plant hormones involved in root to shoot communication? Adv. Bot. Res. 19:103-186.

12. Kuiper, D., Schuit, J., and Kuiper, P. J. C. 1988. Effects of internal and external cytokinin concentration on root growth and shoot to root ratio of Plantago major ssp. pleiosperma at different nutrient conditions. Planta Soil 111: 231-236.

13. Legocka, J., and Szweykowska, A. 1985. The role of cytokinins in the development and metabolism of barley leaves. III. The effect on the RNA metabolism in various cell compartments during senescence. J. Pflanzenphysiol. 102:363-371.

14. Letham, D. S., and Palni, L. M. S. 1993. The biosynthesis and metabolism of cytokinins. Annu. Rev. Plant Physiol. 34:163-197.

15. Liu, Z., and Bushnell, W. R. 1986. Effect of cytokinins on fungus development and host response in powdery mildew of barley. Physiol. Mol. Plant Pathol. 29:41-52.

16. López-Carbonell, M., Alegre, L., Prinsen, E., and Van Onckelen, H. 1994. Effects of water stress on cellular ultrastructure and on concentrations of endogenous ABA and IAA in Fatsia japonica leaves. Plant Growth Regul. 14:29-35.

17. López-Carbonell, M., Alegre, L., and Van Onckelen, H. 1994. Changes in cell ultrastructure and endogenous $\mathrm{ABA}$ and IAA concentrations in Fatsia japonica leaves under polyethylene glycol-induced water stress. Plant Growth Reg. 15:165-174.
18. Mostowska, A., Siedlecka, M., and Parys, E. 1996. Effect of 2.2'-bipyridyl, a photodynamic herbicide, on chloroplast ultrastructure, pigment content and photosynthesis rate in pea seedlings. Acta Physiol. Plant. 18:153-164.

19. Mothes, K. 1964. The role of kinetin in plant regulation. Pages 131-140 in: Régulateurs Naturels de la Croissance Végetal, Centre Nationale de la Recherche Scientifique, Paris.

20. Murphy, A. M., Pryce-Jones, E., Johnstone, K., and Ashby, A. M. 1997. Comparison of CK production in vitro by Pyrenopeziza brassicae with other plant pathogens. Physiol. Mol. Plant Pathol. 50:53-65.

21. Prinsen, E., Redig, P., Strnad, M., Galis, I., Van Dongen, W., and Van Onckelen, H. 1995 Quantifying phytohormones in transformed plants. Pages 245-262 in: Methods in Molecular Biology. Vol. 44, Agrobacterium Protocols. K. M. A. Gartland and M. R. Duvey, eds. Humana Press Inc., Totowa, NJ.

22. Ristic, Z., and Cass, D. D. 1992. Chloroplast structure after water and high temperature in two lines of Zea mays L. that differ in drought resistance. Bot. Gaz. 152:186-196.

23. Ristic, Z., Gifford, D. J., and Cass, D. D. 1992. Dehydration, damage to the plasma membrane and thylakoids and heat shock proteins in lines of maize differing in endogenous ABA and drought resistance. J. Plant Physiol. 139:467-473.

24. Salisbury, F. B., and Ross, C. W., eds. 1992. Cytokinins. Pages 382-392 in: Plant Physiology. Wadsworth Inc., Belmont, CA.

25. Soejima, H., Sugiyama, T., and Ishihara, K. 1995. Changes in the chlorophyll contents of leaves and in levels of cytokinins in root exudates during ripening of rice cultivars Nipponbare and Akenohoshi. Plant Cell Physiol. 36:1105-1114.

26. Spurr, A. R. 1969. A low-viscosity epoxy resin embedding medium for electron microscopy. J. Ultrastruc. Res. 26:31-43.

27. Thomas, J. C., Smigocki, A. C., and Bohnert, H. J. 1995. Light-induced expression of ipt from Agrobacterium tumefaciens results in cytokinin accumulation and osmotic stress symptoms in transgenic tobacco. Plant Mol. Biol. 27:225-235.

28. Van Staden, J., Upflod, S. J., and Drewes, F. E. 1994. Cytokinins in green and yellow leaflets of Schefflera arboricola. S. Afr. J. Bot. 60(5):293-294.

29. Vizárová, G. 1993. Participation of phytohormones in defensive reaction to biotrophic fungi. Agriculture (Lond.) 39:545-552.

30. Vizárová, G., Shashkova, L. S., and Andreev, L. N. 1988. On the question of the relationship between free zeatin content and resistance of wheat to biotrophic fungi. Acta Phytopathol. Hung. 23:389-392. 